\title{
Public History, Invisibility, and Women in the Republic of Ireland
}

\author{
Maeve Casserly and Ciaran O'Neill
}

\begin{abstract}
It seems that Ireland is lagging behind other nations in gender balance in promoting and exhibiting its history. This article seeks to interrogate current representations of women within what can be called "public history" in Ireland. It will also contextualize the integration of women as both creators and subjects of history over recent years. It will point to inadequacies, of course, but also examples of great practice that bodes well for the future.
\end{abstract}

KEY WORDS: Ireland, women's history, museums, Rosie Hackett Bridge

It is great to see powerful, strong women out in front especially in this time and place as these women wouldn't really have been talked about before.

As any actress knows, female characters can sometimes only have bit-partsyou know, the girlfriend or the wife-so this was very exciting. ${ }^{1}$

To think men \& women gave their lives so the Irish could sit around moaning about aTV show with their imaginary friends online. \#rebellion (@colmtobin). ${ }^{2}$

In January 2016 the Irish state broadcaster, RTÉ, aired its five-part television drama series Rebellion to mixed reviews nationally. ${ }^{3}$ Launched amid an array of artistic, documentary, and current affairs programming for TV, radio, and online content as well as major public events, Rebellion was billed as RTÉ's major contribution to the 2016 centenary commemorations of the Easter Rebellion against British rule of Ireland, and it was eagerly anticipated. ${ }^{4}$ The series was a very modern creation.

I Charlie Murphy and Sarah Greene talk to the Irish Film and Television Network about "Rebellion," January 3, 20I6, http://www.iftn.ie/news/?actI =record\&only $=\mathrm{r} \&$ aid $=73 \& \mathrm{rid}=4288868 \&$ $\mathrm{tpl}=$ archnews\&force $=\mathrm{I}$. Charlie Murphy and Sarah Greene starred as the female leads in RTÉ's Rebellion.

2 Colm Tobin, Twitter post, January 24, 20I6, http://www.twitter.com/colmtobin.

3 Ian O'Doherty, "RTE's Rebellion 'Visibly Creaking under the Weight of Its Own Daft Expectations," Irish Independent, January 23, 2016.

4 Bernice Harrison, "RTÉ Rising to Challenge with I9ı6 Programming," Irish Times, November I2, 20I5; Rayna Connery, "RTÉ Unveils First Episode of Rebellion as Part of RTÉ I9I6," RTÉ press release, December 2I, 20I5.

THE PUBLIC HISTORIAN, Vol. 39, No. 2, pp. IO-30 (May 20I7). ISSN: 0272-3433, electronic ISSN 1533-8576. (C) 2017 by The Regents of the University of California and the National Council on Public History. All rights reserved. Please direct all requests for permission to photocopy or reproduce article content through the University of California Press's Reprints and Permissions web page, http://www.ucpress.edu/journals.php?p=reprints. DOI: https://doi.org/Io.I525/tph.20I7.39.2.IO. 
Partially funded through a deal with the Parisian-based company Zodiak Media and syndicated with Sundance TV, the series retold the story of the rebellion of I9I6 with two crucial differences from the traditional account: it narrated it through the lives of three young women, and it emphasized the impact of the rebellion on ordinary people in the capital city of Dublin. As such, and despite its lukewarm reception, Rebellion is indicative of the broad themes of the 2016 centenary program. It told a familiar story, but foregrounded women and civilians within an updated traditional narrative for broad public consumption. This aspect of the drama was one of the few elements that received widespread acclaim, with viewers, actors, and the writer all celebrating this as the intended selling point of the series. ${ }^{5}$

Colm Tobin's tweet, above, captures several aspects of how the Irish reacted to history as it was performed in public in 20I6. He playfully lampoons the ambivalence shown by the Irish public in response to Rebellion, and he includes a gnomic reference to one of the classic ripostes of Irish society, the "was it for this?" so often asked of contemporary values when juxtaposed with the sacrifices of the martyred revolutionaries of I9I6. More than that, it shows the importance of social media as both a democratized space for critical comment, and as an instant barometer of the reception of any historical narrative or production.

In this article we aim to interrogate the positioning of women in public historical contexts in recent years, taking the Republic of Ireland as our focus. We will point to inadequacies, of course, but also to examples of excellent public historical practice that bode well for the future. These include the use of social media to highlight the lack of representation of women in Irish history and the use of feminist dialogue and agendas in public exhibitions and the progressive claiming of public space. Furthermore, there is an ongoing dialogue surrounding the shifting prominence of ordinary female figures over the iconic and their depiction and popularity in mainstream Irish history.

Since its creation in 1949, the Republic of Ireland has widely been considered a conservative and highly religious society. From the mid-r99os, however, there has been an increasing secularization of Irish society alongside the enactment of several progressive social measures, culminating in June 2015 in the passing by popular vote of the thirty-fourth amendment of the constitution, ensuring marriage equality. ${ }^{6}$ It is clear that Irish society is in a state of transition. Societal attitudes to LGBTQ identities are in a state of flux, and the subject of women's history is prominent in current popular and academic historical debate and research. ${ }^{7}$ Positive moves

5 See “4 Questions with Rebellion Star Perdita Weeks," Sundance TV, April I, 20I6, http://www .sundance.tv/series/rebellion/blog/20I6/o4/4-questions-with-rebellion-star-perdita-weeks; " "Rebellion' Creator Celebrates Role of Women in the Rising," Irish Times, January 9, 2016.

6 "Ireland becomes First Country to Approve Same-Sex Marriage by Popular Vote," Irish Times, May 23, 20I5. For statistics on declining religiosity across the republic see Eoin O'Mahony, Practice and Belief among Catholics in the Republic of Ireland (Dublin: Irish Catholic Bishops Conference, 20II).

7 For more on the debate over the so-called "feminization" of the Easter Rising centenary see Úna Mullaly, "Why Women Have Risen to the Top in I9ı6," Irish Times, March 28, 2016; Victoria 
towards the inclusion of women's history in the mainstream historical narrative include a recent proliferation of scholarly work on women's history and an increased awareness and debate surrounding the need for greater gender balance and equality in the academic workplace. We can clearly trace an expansion of women's history societies, conferences, and debates, and of the presence of women in popular and public history through memorials, plaques, statues, and exhibitions. In addition to this, we can begin to detect a move away from some of the more clichéd tropes of the romantic revolutionary heroine that, up until recently, dominated the popular representation of women in histories of the republic. Thus, although certain well-known revolutionary women, such as the "rebel Countess" Constance Markievicz, have remained prominent in this commemorative cycle, others have begun to emerge from the shadows. ${ }^{8}$ Through the continuing debate over the merits of women's history versus gender history; the shift in focus from the iconic to the ordinary in public figureheads; the increasing use of social media and crowdsourcing to reach new audiences and forge new communities; and a progressively more influential feminist agenda narrating exhibitions and public space, there is an ongoing and ever more active reexamination of women's history as part of Irish public history. Despite the difficulties encountered by women in the historical profession and continuing under- and misrepresentation of female figures within history, an increasing number of female-centered projects, exhibitions, and publications are adding nuance to and insight into the study of Irish history as a whole.

\section{Public History and Women's History}

Public history and women's history are in some senses historically and conceptually linked. Both emerged from the radical repositioning of historical work in the I96os and I970s, as Edith Mayo's article in an early issue of The Public Historian noted. ${ }^{9}$ By the mid-I99os, scholars such as Dolores Hayden were explicitly linking both approaches in their own practice. Hayden argued that public history involved making the invisible visible, and she advocated for a more inclusive, postmodern public space to "recover" previously unheard voices of women and minorities. ${ }^{10}$ These connections are more clearly acknowledged in the United States than in

White, "True Heroines of rgr6 Forgotten about in an Attempt to Feminise the Rising," Irish Examiner, March 3I, 2016.

8 "Just Who Was Constance? The Misunderstood Countess," Irish Independent, March 20, 2016; "Women of 1916," Irish Times, February 15, 2016; "Women Played Key and Courageous Role in r9ı6," Irish Times, January 17, 20I6. See also the proposed renaming of the new National Children's Hospital after revolutionary and social activist Dr. Kathleen Lynn: "The Forgotten Heroines of the Easter Rising," Irish Times, January 28 20I6; Seven Women (a documentary drama produced for RTÉ focusing on the lives of a diverse number of women involved in the Easter Rising such as Markievicz, Margaret Skinnider, Helena Molony, and Aoife de Búrca), broadcast on March 20, 2016.

9 Edith P. Mayo, "Women's History and Public History: The Museum Connection," The Public Historian, 5 no. 2 (Spring 1983): 63-73.

Io Dolores Hayden, The Power of Place: Urban Landscapes as Public History (Cambridge, MA: MIT, I996), xiii. 
Ireland, as evidenced by the January 2016 congressional committee meeting on "Women's History and Public History" in Washington, DC, to consider the future plans for a US women's history museum (the latest element of a campaign to build a physical museum that stretches back twenty years to 1996). ${ }^{11}$ In Ireland, as in the UK, the term "public history" has only just begun to enter into popular and academic discourse, although women's history has a much longer and deeper resonance. ${ }^{12}$

The recent publication of Sexual Politics in Modern Ireland, an innovative collection of essays edited by members of the leading women's history group, the Women's History Association of Ireland (WHAI), has given the notion of the "body politic" a special emphasis. ${ }^{13}$ Sexual Politics marks a culmination of the evolving and intermingling fields of gender and women's history in Ireland since the r97os. The collection centers on the notion of the female body as a political entity around which legislative rights, gender and behavioral norms, and societal mores can be built. Sexual Politics stems from a number of key texts in the field of women's history in Ireland, the first and most influential of which was Margaret MacCurtain and Donnchadh O'Corráin's pioneering collection Women in Society: The Historical Dimension (1978). ${ }^{14}$ It included essays from dynamic young historians in the field such as Katherine Simms and Margaret Daly, as well as Senator Mary Robinson, later the first female president of the republic. Women in Society was published by Catherine Ross of Arlen Press, after having previously been rejected by three publishers. It was reprinted in I979 and subsequently republished by Greenwood Press in the United States. ${ }^{15}$ Its focus on controversial topics such as gender, sex, and religion and innovative use of sources and methodologies had a major impact on the practice of Irish women's history, and many recent publications still reference it as a landmark text in the field. ${ }^{16}$

Over a decade later, Maria Luddy and Cliona Murphy's Women Surviving broke new ground by attempting not only to write women back into history, but by concentrating on those that had been marginalized and underrepresented. Topics

II See American Museum of Women's History Commission, http://www.womenshistory commission.org/about-us/mission/. For more on that controversial campaign, see Andrea Stone and Christina Wilkie, "National Women's History Museum Makes Little Progress after r6 Years," Huffington Post, April I3, 20I2; Manon Perry, "National Women's History Museum \& Material Culture Wars," History@Work (blog), May 23, 20I4, http://ncph.org/history-at-work/national -womens-history-museum-wars/.

I2 For more on public history in Ireland see Thomas Cauvin and Ciaran O'Neill, "Negotiating Public History in the Republic of Ireland: Collaborative, Applied and Usable Practices for the Profession," Historical Research (forthcoming 2017); Gearóid Ó Tuathaigh, "Commemoration, Public History and the Professional Historian: An Irish Perspective," Estudios Irlandeses 9 (2014): 137-45.

I3 Jennifer Redmond, Sonja Tiernan, Sandra McAvoy, and Mary McAuliffe, eds., Sexual Politics in Modern Ireland (Dublin: Irish Academic Press, 2015).

I4 Margaret MacCurtain and Donnchadh O'Corráin, eds., Women in Irish Society: The Historical Dimension (Dublin: Arlen House, 1978).

I5 Margaret MacCurtain, "Foreword," in Irish Women's History, ed. Alan Hayes and Diane Urquhart (Dublin: Irish Academic Press, 200I), p. xii.

I6 See introductions to Maria Luddy and Cliona Murphy, Women Surviving: Studies in Irish Women's History in the Nineteenth and Twentieth Centuries (Dublin: Poolbeg, I989); Hayes and Urquhart, Irish Women's History; Redmond et al., Sexual Politics in Modern Ireland. 
in this edited collection included prostitutes, nuns, female paupers, and women as "breadwinners and providers."17 Luddy and Murphy proposed that the study of women's history demands "the re-evaluating, the re-organising and the reinterpreting of our knowledge of the past," creating a narrative in which women are no longer seen as passive observers or victims of history, but as "active agent[s] in the historical process."18 Following the model set by Women in Society, this reevaluation would have a crucial effect on the sources used by historians. Luddy and Murphy's study looked at the ordinary rather than the exceptional, and through a diverse range of topics, demonstrated how groups of Irish women and individuals responded to society and the realities of their everyday lives. An agenda for women's history appeared in 1992, quite late, in Irish Historical Studies. ${ }^{19}$ This occurred in the wake of a divisive national debate on the exclusion of women from The Field Day Anthology of Irish Writing (a three-volume collection meant to represent the Irish literary canon) the previous year. It also followed the publication of key texts in gender history globally, such as Joan Wallach Scott's Gender and the Politics of History (I988) and the 1989 launch of the journal Gender and History.

In recent years there has been a proliferation of texts on Irish women's history. James Kelly and Elizabeth Fitzpatrick's Domestic Life in Ireland, published in 2012 by the Royal Irish Academy, is a broad survey study of domestic life from the first Neolithic settlements to the bespoke houses of the Celtic Tiger era. In it twenty scholars across multidisciplinary backgrounds examined changes in design, decoration, material goods, and fashion; rituals and superstitions of daily life; and divides between rural and urban, male and female, rich and poor. Domestic Life marked an important shift in including women's history in mainstream social history. Examples of other recent popular studies on Irish women in the revolutionary period include Senia Pašeta's Irish Nationalist Women (2013), Sinead McCoole's Easter Widows (2014), Lucy McDiarmid's At Home in the Revolution (2015), and Richmond Barracks in 1916: WeWere There: 77 Women of the Easter Rising by Mary McAuliffe and Liz Gillis (20I6). ${ }^{20}$

Over the last several decades we have endured a circular debate about the appropriate relationship between gender and women's history, part of a much older circular debate about the benefits and cost of integrating women's history into mainstream history. Linda Connolly has argued that merging women's history with gender history would compromise the field of women's history and that more groundwork needs to be done on this specialist topic before it can be integrated into gender

I7 Mary Cullen, "Breadwinner and Providers," in Luddy and Murphy, Women Surviving, 85-II6.

I8 Maria Luddy and Cliona Murphy, "Cherchez la femme': The Elusive Woman in Irish History," in Luddy and Murphy, Women Surviving, I.

I9 Margaret MacCurtain, Mary O’Dowd, and Maria Luddy, “An Agenda for Women's History in Ireland, 1500-1900," Irish Historical Studies 28, no. 109 (May 1992): I-37.

20 Senia Pašeta, Irish Nationalist Women, 1900-1918 (Cambridge: Cambridge University Press, 2013); Sinead McCoole, Easter Widows: Seven Irish Women Who Lived in the Shadow of the 1916 Uprising (London; Doubleday Ireland, 2014); Lucy McDiarmid, At Home in the Revolution: What Women Said and Did in 1916 (Dublin: Royal Irish Academy, 2015); Mary McAuliffe and Liz Gillis, Richmond Barracks: We Were There: 77 Women of the Easter Rising (Dublin: Four Courts Press, 2016). 
history, or women will be lost in obscurity all over again. ${ }^{21}$ Others argue that gender history offers a more balanced narrative. ${ }^{22}$ The circularity of the debate is indicative of, if anything, its difficulty and importance. How does this decades-old debate correlate to contemporary discussions about gender equality in academic history?

\section{Gender Equality in Academia: Women Writing History}

The extent of gender inequality within Irish academia is actively debated. The recent failure of four higher education institutions to achieve Athena Scientific Women's Academic Network (SWAN) accreditation for gender equality practices highlighted a systemic issue in Irish higher education, and it followed an academic promotions controversy at the National University of Ireland (NUI) Galway in 20I4. ${ }^{23}$ The UK-based Athena SWAN Charter addresses work in most academic disciplines in terms of representation, work environment, student progress into academia, and the journey through career milestones. The most recent nationwide surveys undertaken by the Higher Education Authority (HEA) in 2013 and 2016 revealed that the ratio of men to women at full professorial rank across the university sector averaged at 8I percent male to i9 percent female, with a much more encouraging ratio of 50 percent male and female at the entry level. ${ }^{24}$ Within academic history departments we can trace a similarly clear pattern of female "juniority" across multiple departments. This, of course, does not neatly connect with questions of women's history in public per se. After all, not all female historians should be thought to have an interest in women's history, but their positions as historians in the public eye is nevertheless relevant to our survey. Within the academy women's history is represented by a revitalized Women's History Association of Ireland (founded in 1989), which is connected to the International Federation for Research in Women's History. Trinity College Dublin (TCD) has an active Centre for Gender and Women's History, while University College Dublin (UCD) has a more contemporary-focused Centre for Women's Studies, attached to the School of Social Justice. Some important student-led initiatives have emerged from both centers in recent years, with the Irish Feminist Network emerging from TCD in 20I0. Women's history itself continues to be studied almost entirely by female historians.

21 Linda Connolly, "Feminist Scholarship and Contemporary Ireland," Irish Review 24 (Autumn I999): I57-6r.

22 Cliona Murphy, "Women's History, Feminist History or Gender History?", Irish Review I2 (Spring/Summer 1992): 2I-26; David Fitzpatrick, "Women, Gender and the Writing of Irish History," Irish Historical Studies (May 1991): 267-73.

23 "UL tops gender equality table for academic staff," Irish Times, December 3, 2015; Caroline Crawford, "NUIG Told to Pay Lecturer $€$ 70, oo o for Gender Bias," Irish Independent, November I8, 2015.

24 See data released by HEA, December 3, 20I4 http://www.hea.ie/news/gender-and-academic -staff; HEA National Review of Gender Equality in Irish Higher Education Institution (June 2016), http://www.hea.ie/sites/default/files/hea_review_of_gender_equality_in_irish_higher_education. pdf. Athena SWAN is an Equality Challenge Unit initiative and was founded in 2005 to encourage and recognize the careers of women in science, technology, engineering, and math (STEM) subjects and has since expanded to cover all academic disciplines. It has a Gold, Silver, and Bronze award structure. 
The Irish history profession is, as elsewhere, composed of a broad spectrum of scholars, including those engaged in history as their full time occupation, those who have a part-time stake in the field, and those early career historians caught in the liminal and increasingly precarious world of adjunct or zero-hour contract lecturing. ${ }^{25}$ Taking those historians currently on staff at Ireland's nine universities, the number of women at senior levels is dramatically lower than for men, and with current rates of representation among junior faculty, there is little chance that the picture will change in the next decade or so unless there is a clear change in hiring practice and internal promotion. This means that Irish history departments are considerably behind the curve in gender equality terms. This is in marked contrast to gender progression rates in the United States, where recent research highlights that among history faculty born between 1965 and 1980, progression rates to tenured and professorial levels were about the same between male and female faculty, and that in terms of senior academic positions females are progressing faster than in Ireland. Elsewhere, studies in the UK and Scandinavia have concluded that female academics are more vulnerable to an early career exit than their male counterparts, and that a "cumulative disadvantage" is evident in female underpromotion. ${ }^{26}$

\begin{tabular}{|c|c|c|c|c|c|c|}
\hline University & FT staff ${ }^{27}$ & M & $\mathrm{F}$ & Profs & M & $\mathrm{F}$ \\
\hline NUIG & I6 & Io & 6 & 2 & 2 & c \\
\hline UCC & 26 & 2I & 5 & 2 & 2 & \\
\hline UCD & 26 & I7 & 9 & 3 & 3 & \\
\hline MU & 20 & I2 & 8 & 6 & 4 & 2 \\
\hline UL & 7 & 5 & 2 & 2 & I & \\
\hline TCD & 27 & $2 \mathrm{I}$ & 6 & I2 & II & \\
\hline DCU & 7 & 4 & 3 & 2 & 2 & 0 \\
\hline UU & 17 & I4 & 3 & 2 & 2 & $c$ \\
\hline QUBw & $3^{\mathrm{I}}$ & 20 & II & 9 & 7 & 2 \\
\hline Totals & I74 & I23 & $5^{\mathrm{I}}$ & 36 & 30 & 6 \\
\hline
\end{tabular}

25 See Aline Courtois and Theresa O'Keefe, "Precarity in the Ivory Cage: Neoliberalism and Casualisation of Work in the Irish Higher Education Sector," Journal of Critical Education Policy Studies I3, no. I (June 2015): 43-66; Belinda Probert, “I Just Couldn't Fit In': Gender and Unequal Outcomes in Academic Careers," Gender, Work and Organization I2, no. I (January 2005): 50-72; Narelle Lemon and Susanne Gravies, eds., Being "In and Out": Providing Voice to Early Career Women in Academia (Rotterdam: Sense, 2014).

26 See Standing Still: The Associate Professor Survey, Report of the Committee on the Status of Women in the Profession (New York: Modern Languages Association, 2009), https://apps.mla.org/pdf/ cswp_finalo42909.pdf; Barbara Bagilhole, "Survivors in a Male Preserve: A Study of British Women Academics' Experiences and Perceptions of Discrimination in a UK University," Higher Education 26, no. 4 (December 1993): 43I-47; Mathias Wullum Nielsen, "New and Persistent Gender Equality Challenges in Academia" (PhD dissertation, University of Aarhus, 2015), 34I.

27 This information pulled from departmental websites is accurate to December 2016. Prof. means those above Senior Lecturer level. Full names of Irish universities listed: National University of Ireland Galway (NUIG); University College Cork (UCC); University College Dublin (UCD); Maynooth University (MU); University of Limerick (UL); Trinity College Dublin (TCD); Dublin City University (DCU); Ulster University (UU); Queens University Belfast (QUBw). 
Women's chronic underrepresentation in permanent posts suggests an ingrained resistance to the hiring of women in Ireland's academic departments, and a resistance that reflects a systemic inequality between men and women across the higher education sector, especially at senior levels. ${ }^{28}$ The gender breakdown for the representative body for independent history professionals, the newly formed Irish Association for Professional Historians, shows that there are 82 women among its 166 members. Likewise, statistics for recently qualified history $\mathrm{PhDs}$ at TCD over the past five years show a bias in favour of male historians, but not as dramatic a bias, with 44 male $\mathrm{PhDs}$ against 29 female $\mathrm{PhDs}$ graduating since 20I0. The Irish history profession has remained unusually resistant to the integration of female historians despite the high profile of several well-known women historians within the profession from the early twentieth century. ${ }^{29}$ The vexed question of women performing history in front of the wider public is of equal or perhaps greater importance to the fight for equality within the academy. Several advocacy groups exist already, but the issue of equal exposure and visibility is very far from being definitively resolved.

\section{Conferences and Academic Engagement}

Women's history in Ireland today is a diverse and evolving field. Both traditional and modern forms of public engagement and dissemination of knowledge are practiced by members of women's history organizations such as the Women's History Association of Ireland (WHAI) as well as by the Women's Museum of Ireland. The WHAI is an important body that brings together scholars from across the field of women's history and women's studies in Ireland. Its annual conferences have marked significant historical moments in Irish history, such as the onehundredth anniversary of the foundation of women's auxiliary group Cumann na mBan (The Irishwomen's Council) in 2or4. The two-day conference unveiled a special issue stamp and was opened by Minister for Arts, Heritage and the Gaeltacht Jimmy Deenihan. ${ }^{30}$ The diverse membership of the WHAI and the conference and event attendees attest to the appetite for insights from women's history on both "mainstream" and "alternative" narratives of the past. ${ }^{31}$ Several publications ranging over a wide number of topics have resulted from WHAI conferences, such as

28 This systemic issue has recently been acknowledged by the Higher Education Authority in Ireland. See Joe Humphreys, “Gender Inequality: A Systemic Issue for Irish Higher Education,” Irish Times, May 28, 2015. For medium-term statistical evidence to support the idea see Alfric O'Grada, Caitriona Ní Laoire, Geraldine Boylan, Carol Linehan, and Linda Connolly, Through the Glass Ceiling: Career Progression Programme and Strategy for Female Academics and Researchers (Cork: ISS 2 I and University College Cork, 20I2), http://www.ucc.ie/en/media/research/iss2I/GlassCeilingFinalOctober 20I2.pdf.

29 See Nadia Claire Smith, A "Manly Study"? Irish Women Historians 1868-1949 (Basingstoke: Palgrave MacMillan, 2006).

30 Women's History Association of Ireland, "Cumann na mBan ıoo," (conference website), http://womenshistoryassociation.com/events/cumann-na-mban-ıoo/.

3I Redmond et al., "Introduction," Sexual Politics in Modern Ireland, 3. 
Judith Harford and Claire Rush's Have Women Made a Difference? (2010). ${ }^{32}$ This collection, originating from a conference honoring one hundred years of women in university education, brought together papers from prominent scholars in the fields of literature, education, nursing, history, social policy, and women's studies. The book examines the complexity of women's position within the academy and outlines the progress of women's role in university education from the nineteenth century to the present day. Bernadette Whelan's edited collection Women and Paid Work in Ireland, 1500-1930, which drew together a diverse range of scholarship on women's employment in Ireland, resulted from the I998 WHAI conference at the University of Limerick. It highlights the international context of Irish women's paid work, arguing attitudes about women working for wages were similar across Europe in the modern period. ${ }^{33}$ Elaine Farrell's edited collection, She Said She Was in the Family Way, arose out of a WHAI conference at Queen's University Belfast in 2010 that examined pregnancy and infancy in Ireland from the seventeenth to the twentieth century. ${ }^{34}$ In her forward, Mary O'Dowd points to the importance of texts that not only represent significant contributions to the field of women's history but also to the study of childhood, parenthood, labor, and domesticity, as well as other topics. ${ }^{35}$ O'Dowd describes women's history as one of the driving forces behind the development of social history in Ireland, in contrast to England, where a renewed interest in social history in the late twentieth century led to the emergence of women's history. ${ }^{36}$ Furthermore, historians of women's and gender history have played an important role in alerting the general public to unknown aspects of its past, such as the recent revelations about ill treatment of vulnerable inmates in Magdalene asylums and mother and baby homes. Many of these historians have aided in government-established enquires to detail the political, economic, religious, and social contexts of these institutions, which have profoundly affected not only women's history, but the overall relationship of the Irish people with their past. ${ }^{37}$

The Women's Museum of Ireland was founded in November 2012 by a small group of female Trinity College graduates who started the discussion about the need for a museum dedicated to women in Dublin. ${ }^{38}$ The museum's manifesto seeks to promote the formal recognition of the role of women in Irish history and

32 Judith Harford and Claire Rush, eds., Have Women Made a Difference? Women in Irish Universities, 1850-2010 (New York: Peter Lang, 2010).

33 Bernadette Whelan, ed., Women and Paid Work in Ireland, 1500-1930 (Dublin: Four Courts Press, 2000).

34 Elaine Farrell, ed." "She Said She Was in the Family Way": Pregnancy and Infancy in Modern Ireland (London: University of London, School of Advanced Study, Institute of Historical Research, 20I2).

35 Mary O'Dowd, "Foreword," in Farrell, She Said She Was in the Family Way, xix.

36 O’Dowd, "Foreword," xix.

37 Maria Luddy, "Foreword," in Redmond et al., Sexual Politics in Modern Ireland, xiv.

38 Jean Sutton, interviewed by Karl McDonald, “The Half That Just Haven't Been Mentioned Yet: Women's Museum of Ireland Interview," Totally Dublin, March 4, 2013, http://totallydublin.ie/ more/opinion/womens-museum-of-ireland/2/. 
to educate the public about the contribution of women to political, social, and cultural history in Ireland and abroad. ${ }^{39}$ The museum currently has no physical location and exists purely as a virtual entity. The online format is based around biographies of important and often "forgotten" female figures. The detailed biographies span across centuries of Irish history and all social milieus, and include Peg Plunkett, an infamous brothel madam in eighteenth-century Dublin; Mary Moore, key conspirator in the failed 1798 Irish rebellion; and Ellen Hutchins, Ireland's first female botanist who gained international prestige for her contributions to the field in the early nineteenth century. ${ }^{40}$

Since its establishment in 2012 the Women's Museum has organized one physical exhibition, Monsters of Creation: A Snapshot of Women in Higher Education, which ran throughout March 20I3 at Trinity College Dublin as part of International Women's Week. ${ }^{41}$ The virtual nature of the museum offers both advantages and disadvantages for visitor engagement, brand recognition, and overall impact. The museum's "collection" is based around a body of open-access online research rather than physical artifacts, which should allow for a fluid and energetic form of curation. ${ }^{42}$ Visitors can easily connect with the museum via its website, share its contents via Facebook or Twitter, and are encouraged to contribute biographies and blog entries. ${ }^{43} \mathrm{~A}$ major flaw in the museum's organization, however, is with administration of the website and the irregular and inconsistent blog and biography entries (averaging one every two months). ${ }^{44}$ For example, in August 2015 theWomen's Museum began a crowdsourcing initiative to create a "Women of Dublin" map in collaboration with Dublin City Council. In a blog entry dated August 4, 2015, the Women's Museum put out a call for contributors to the map, which would draw attention to areas of interest around the city with the aim of inspiring the "preservation and recognition" of these sites. ${ }^{45}$ The project would consist of both an interactive map available from the Women's Museum website, and a downloadable version allowing users to self-guide. The hashtag campaign \#WomenofDublin drew a large number of tweets, Facebook posts, and comments when the initial call for submissions was released, but by December 2016 no further progress or comments had been made on the map, and no other blog posts or biographies had been uploaded onto the site. The Women's Museum is an

39 "About the Museum," Women's Museum of Ireland, http://womensmuseumofireland.ie/about. 40 See "Exhibits," Women's Museum of Ireland, http://womensmuseumofireland.ie/articles.

4I "International Women's Week 20I3 Monday 4th March 20I3," Trinity College Dublin, https:// www.tcd.ie/equality/projects/international-womens-week/.

42 Kate Cunningham, interviewed by Karl McDonald, "The Half That Just Haven't Been Mentioned Yet: Women's Museum of Ireland Interview.' Similarly United States' National Women's History Museum does not have a physical building but uses its website to present its diverse and timely exhibitions online.

43 As of December 9, 20I6, the website had 4,245 likes on Facebook and I,920 followers on Twitter; https:/www.facebook.com/WomensMuseumOfIreland/app/ri6943498446376/.

44 See "Blog Archive," Women's Museum of Ireland, http://womensmuseumofireland.ie/blog.

45 "Help Us Put Women Back on the Map," Women's Museum of Ireland, http://womens museumofireland.ie/blog/2015/o8/o4/help-us-put-women-back-on-the-map-of-dublin; "Women's Museum of Ireland Plans New Dublin Map," Irish Times, August 5, 2015. 
interesting venture into what could be a new and dynamic museum that could engage with the exciting challenges of social media, yet, the sporadic and uncoordinated nature of the voluntary body behind the project has not utilized this new communication and curatorial platform. The failure to use the opportunities created by social media and the current momentum behind the popular interest and enthusiasm for women's history has been to the detriment of the museum. ${ }^{46}$ Taken together, the WHAI and the Women's Museum demonstrate the importance of the link between the academy and public history. The university sector continues to operate as an incubator for crossover initiatives at the intersection of public and women's history, even as it struggles for equality within the academy.

\section{Exhibiting Women: A Feminist Dialogue}

Over the past decades a diverse range of female-centric exhibitions have been held in the Republic of Ireland that have challenged the narrative of women's history as being outside the mainstream. These multifaceted and nuanced depictions of women in the public sphere can broaden the popular understanding of the position of women in Irish history. ${ }^{47}$ Kilmainham Gaol (a stronghold of masculine militant-nationalist iconography) launched the exhibition Guns and Chiffon: Women Revolutionaries in May I997 to coincide with the release of Sinead McCoole's book of the same title at a ceremony opened by President Mary Robinson. ${ }^{48}$ The book and exhibition depicted female revolutionaries as active agents in the struggle for Irish freedom and broadened the debate on the role of women in Irish republican nationalism beyond renowned figures such as Countess Markievicz and Maud Gonne to rank-and-file members of organizations such as Cumann na mBan and Inghinidhe na hÉireann (Daughters of Ireland). ${ }^{49}$ Likewise, the Schools of English, Sociology, and Applied Social Studies, University College Cork, collaborated on "Women in Irish Society", a three-year interdisciplinary project focused on the lives of ordinary women conducted in Munster. $^{50}$ The venture resulted in an exhibition, launched in January 2003, which dealt with three integrated themes in Irish women's lives: women in paid employment in Munster 1936-6o; feminism and the Irish women's movement; and Munster women

46 For an example of a successful crowdsourcing campaign, see the National Library of Ireland's Flickr Commons account, which uses research information from voluntary contributors to update its photographic collection: https://www.flickr.com/photos/47290943@No3/.

47 For further discussion on the value of exhibitions and interactive community initiatives in adding depth to the public understanding of "mainstream" history, see Leondra Burchall's "Bringing History Back to Life," The Public Historian 32, no. 4 (Fall 2010): 62-68.

48 "Review: Guns and Chiffon," History Ireland 5, no. 2 (Summer 1997), http://www.history ireland.com/revolutionary-period-I9I2-23/guns-and-chiffon/; Mary Russell, "Guns and Roses," Irish Times, May 22, I997.

49 Sinead McCoole, Guns and Chiffon: Women Revolutionaries and Kilmainham Gaol, 19161923 (Dublin: Stationary Office, I997).

50 "Women in Irish Society Project," University College Cork, http://www.ucc.ie/archive/wisp/ aboutw.html. For further information, see the press release, "UCC Exhibition Celebrates "Women and Irish Society' Project," January 3I, 2002, University College Cork, http://www.ucc.ie/archive/ opa/pr/PressReleaseIrishWomen.html. 
writers. The exhibition was one strand of a scheme that also comprised academic publications, compilation of archival catalogues, and oral testimonials. ${ }^{51}$

In many cases the issue of inadequate source material still provides a major difficulty in curating exhibitions focused on the lives of ordinary women. Because of this, archives such as the Irish Countrywomen's Association (ICA), held in the National Library of Ireland, are an indispensable resource. In 2oro the centenary of the ICA's founding instigated a collaborative partnership between the Mayo Guild of the ICA and the National Museum of Ireland that resulted in an exhibition in the National Museum of Decorative Arts and History. ${ }^{52}$ The exhibition showcased manuscript material from the National Library holdings as well as items made by past and current guild members across Ireland, including crocheted wedding dresses, wall hangings, and woven basks. The ICA ran knitting and craft-exchange workshops hosted by the museum. Collaborative projects between communitybased groups such as the ICA and national institutions such as the National Library and National Museum are fundamental to the shift of emphasis in women's history from the iconic to the ordinary. National institutions provide the necessary infrastructure and funding to reach large audiences, while collaboration allows for the participation of nonacademics in the narration of their community's history. However, as these projects focused on the work of one organization (ICA) or profession (writers) it is difficult to compile a broad-spectrum study of the social history of ordinary Irish women solely from these sources.

\section{Modern Wife, Modern Life: Sourcing Objects}

The Modern Wife, Modern Life: An Exhibition of Women's Magazines and Objects from 1960s Ireland exhibition, curated by academic historian Ciara Meehan and first displayed in the Print Museum in Dublin, used an array of source material to create an in-depth narrative of the "ordinary" I96os Irish housewife. The interactive exhibition and accompanying cross-country "roadshows" demonstrate new ways to gather material, memories, and information from oral testimony and are the first step in a long-term project to publish a comprehensive history of everyday lives in I96os Ireland called "The People's Archive." ${ }^{33}$ Crowdsourcing, particularly through social media, was a major part of the collection building. Recipe books, a wedding dress, and a sewing machine, all of which are accompanied by anecdotal

5I See Tina O’Toole, Dictionary of Munster Women Writers, 180o-20oo (Cork: Cork University Press, 2005). See also the "Irish Women's Movement Archive" and the "Oral History Project on Women in Paid Employment in Munster, 1936-I960" housed in the Boole Library, University College Cork, Ireland.

52 Irish Countrywomen's Association, previous exhibitions, National Library of Ireland http:// www.nli.ie/en/udlist/programme-and-events-previous-exhibitions.aspx?article $=27$ aacdbc- $9 \mathrm{~d} 49$ -4I4f-afcd-b2i6d8o8f $4 \mathrm{~d}_{4}$.

53 Ciara Meehan, interviewed by Maeve Casserly, May 20, 2015, Dublin, transcript in possession of the author. "The People's Archive" will be an oral history project reaching across gender, social, and generational divides akin to the Mass-Observation Archive in the University of Sussex. 
insights into the life of the Irish housewife, are just some of the items that Meehan acquired through a public appeal on local and national radio as well as Facebook and Twitter. Meehan used the items brought along by attendees of the collection days to spark memories for oral testimonies that featured in the final exhibition.

Modern Wife, Modern Life incorporates magazine advertisements from popular Irish magazines such as Woman's Way, Woman's Choice, and Women's View to demonstrate popular depictions of the ideal life. These magazines were not only the most widely read by Irish women in the rg6os, but also responded to and shaped the social changes that swept across the country over the course of the decade. ${ }^{54}$ The I96os was a decade of huge social and economic change and the cult of materialism is apparent in the glossy advertisements found in the magazines. ${ }^{55}$ Modern Wife, Modern Life illustrates the link between the "modern wife," whose reputation was bound up in the presentation of her home and material possessions, with the ideal lifestyle of "modern life" centered on the latest gadgets and technologies. Part of the reason the material element of the exhibition sparked such vivid and personal memories among those interviewed is because these objects formed part of their identity at the time. The exhibition also features published letters from and debates between ordinary readers. The "Letters to the Editor" offer insight into women's views on sex, work, and equal pay and anticipated the changes that we now often associate with the second wave of Irish feminism in the I970s, as seen in publications such as Banshee. ${ }^{56}$

The stereotype of the oppressed housewife chained to the stove is not a prominent feature in Modern Wife, Modern Life. Instead the exhibition explores the expectations of the modern housewife of ig6os Ireland, with the essential message that innovations in household items such as the washing machine were more revolutionary for women's everyday lives than gaining the vote. While this is not a controversial proposal within academic publications on women's history, popular history has not traditionally presented this viewpoint. Meehan goes a long way in challenging the oppressed housewife stereotype; for example, one print is an advertisement for the aptly named "Liberator," a washing machine with an electric timer. ${ }^{57}$ While not playing down the importance of the feminist movement for women's independence, the exhibition is willing to complicate a sometimes simplistic narrative of female domestic suppression.

There is a need for resources on the history of "ordinary" people in Ireland and Modern Wife, Modern Life is trying to meet it, initially, in this small-scale exhibition, through oral history testimonials and the digitization of objects connected to these testimonials. While the Gaelic Athletic Association and the Irish Countrywomen's

54 Meehan interview.

55 See also Lensmen Photographic Archive, The 1960s: Ireland in Pictures (Dublin: O'Brien Press, 20II); Bryan Fanning, The Quest for Modern Ireland: The Battle for Ideas, 1912-1986 (Dublin: Irish Academic Press, 2008).

56 Meehan interview.

57 Modern Wife, Modern Life, National Print Museum, Dublin, July I, 2015. 
Association have produced laudable oral history and grassroots archives, they give an insight into a small and predominantly rural segment of society. Meehan's project aims to be a broad-spectrum collection of memories and material from the everyday lives of all Irish people. ${ }^{58}$ The emphasis is on the public; they are both the subject of the exhibition and active participants in its creation..$^{59}$ Meehan's long-term goal is to create an online "Irish People's Archive" through further public appeals and collection days, which will illustrate the complexities of the lives of ordinary people across geographic, social, and gender divides. This project is reflective of an evolving discussion on alternative means of source acquisition sometimes necessary in women's history (or non-mainstream history) and the merits of crowdsourcing material. Crowdsourcing is not a new phenomenon in the practice of public and digital history; the Flickr account of the US Library of Congress, for example, is longstanding, as are group collaborative cataloguing initiatives in the New York Public Library. ${ }^{60}$ In Ireland crowdsourcing has been used successfully by the "Inspiring Ireland" project through the Digital Repository of Ireland (DRI). In a series of national and international collection days, the public have been invited to bring along items related to the First World War and the Easter Rising from their own family to be digitized, recorded, catalogued, and preserved by DRI and its partners. ${ }^{61}$ A number of thematic exhibitions taken from items from the collection days are available on the project's website, including an exhibition titled Women and the Rising. ${ }^{62}$ Women's history in Ireland is at the foreground of these new enterprises into public history, and projects such as Modern Wife, Modern Life respond to the call to historians and researchers to use diverse and alternative source material issued by Luddy and Murphy in I989.

\section{Women in Public Spaces: Scripting a Nation's Identity}

The cultural geography of a country's capital is an important forum for creating and propagating a nation's identity. Public monuments, sculptures, bridges, parks, and

58 The Oral History Project of the Gaelic Athletic Association (GAA) was the largest oral history project undertaken since the Irish Folklore Commission was established in the r93os. The Boston College Center for Irish Programs compiled thirty thousand recorded testimonials and interviews from members in 2008. Themes addressed included the changing relationship of women with the association, the influence of religion, language, and culture, and the effects of immigration and emigration. For further information on the initiative see https://www.bc.edu/centers/irish/ gaahistory/the-project.html. The material collected has been made available as a searchable digital archive housed in the Gaelic Athletic Association Museum at Croke Park.

59 Leondra N. Burchall, "Emphasis on the Public," The Public Historian 32, no. 4 (November 2010): $62-68$.

6o The US Library of Congress's Flickr Commons Project started in 2008 and now has nearly twenty-six thousand images identified by its large audience of 66,600 followers, https://www.flickr .com/photos/library_of_congress/albums/. The New York Public Library invites the public to "Kill time, make history" by helping to transcribe, identify, cross reference, and digitally align historical maps from its collection with present-day locations; http://www.nypl.org/collections/labs.

6I "Inspiring Ireland," http://www.inspiring-ireland.ie/about/our-project.

62 "I916: Weaving Public and Private Narratives," "Inspiring Ireland", http://www.inspiring -ireland.ie/browse/rgr6-weaving-public-private-narratives. 
street names are the very literal foundations in the "building" of Benedict Anderson's "imagined communities." ${ }^{63}$ Walking through the streets of Dublin, it is often hard to find a place for women in this historical narrative, particularly in public space, beyond the traditional female representations of abstract virtues and ideals or as embodiment of the nation itself. ${ }^{64}$ Dublin's "national boulevard," O'Connell Street, contains no plaque, statue, or monument dedicated to the memory of an Irish historical female figure. Instead women are represented allegorically in the figures of Hibernia, Fidelity, Patriotism, Courage, and Eloquence that stand atop various iconic buildings, or garland the statues of the various great men of Irish history. ${ }^{65}$ Yvonne Whelan writes on this disparity in female representation, separating the monumental iconography of the streets of Dublin into three distinct categories: Dublin in the Empire; post-I922 Free State Dublin; and postmodern Dublin, which tends towards apolitical monuments. ${ }^{66}$ A key example of the forging of a new national identity by the state is An Túr Solais (the Spire), a 398-foot stainless-steel cone that stands in the center of O'Connell Street and is an apolitical, perhaps even meaningless, demonstration of the republic's confidence as a nation. ${ }^{67}$ In terms of public statuary and sculpture, this piece would suggest that the republic has leapt from gender-biased to gender-neutral representation, without a period of restorative or revisionist work in the interim. When the opportunity has arisen to carry out some sort of remedial work of this nature, the reaction has usually been positive, as seen most recently with the decision to name a new bridge over the River Liffey in the city center after Rosie Hackett, a trade unionist active in the Dublin Lockout of 1913 and the rebellion of 1916.

\section{Rosie Hackett Bridge: Crossing a Divide in Postmodern Iconography}

The Rosie Hackett Bridge is popularly (though mistakenly) believed to be the only bridge running across the River Liffey in Dublin City Centre to be named after a woman. ${ }^{68}$ The bridge, which connects Marlborough Street with Hawkins Street,

63 Benedict Anderson, Imagined Communities: Reflections on the Origins and Spread of Nationalism (London: Verso, I99I).

64 Examples taken from Noel Doherty, The Complete Guide to the Statues and Sculptures of Dublin (Dublin: Orpen Press, 2015) include: the representations of Peace and Justice on top of the former Irish House of Parliament (74-77); the Greek god Nike at the foot of the O'Connell Statue (In3-I6); Anna Livia and embodiment of the River Liffey (104); and Ére or Hibernia (75).

65 Doherty, Complete Guide to Dublin's Statues and Sculptures; discussion of monuments to Countess Markievicz can be found in St. Stephen's Green and Townsend Street (44-45 and 66). For further discussion on the symbolism of O'Connell Street, see Yvonne Whelan, "Decoding Symbolic Spaces of Dublin: A Photographic Essay," Canadian Journal of Irish Studies 28, no. 2 (2002-3): 46-73.

66 Yvonne Whelan, Reinventing Modern Dublin: Streetscapes, Iconography and the Politics of Identity (Dublin: University College Dublin Press, 2003).

67 Doherty, Complete Guide to the Statues and Sculptures of Dublin, I2O-2I.

68 Some media reports characterized the Hackett Bridge as the first Liffey bridge named after a woman, though other bridges had once been named for women. Mellows Bridge was formerly Queen's Bridge after Charlotte of Mecklenburg-Strelitz and in 1922 was renamed Queen Maeve's Bridge after the ancient warrior queen; Island Bridge was formerly Sarah Bridge after Sarah Fane, Countess of Westmorland; Rory O'More Bridge was formerly Victoria and Albert Bridge. 
was constructed to link the new Luas metro system between the north and south sides of the capital, and was built between early 2012 and May 20I4. During its construction Dublin City Council invited nominations for the naming of the bridge from the general public, and eighteen thousand people participated. Ten nominations of the eighty-five names put forward were referred to the council's naming committee, which in September 2013 chose Rosie Hackett, a trade unionist and republican revolutionary. ${ }^{69}$ The Rosie Hackett campaign had started the year before by a small group of Labour Youth members spearheaded by Angelina Cox, Jeni Gartland, and Lisa Connell. While there were campaigns for a number of other names on the shortlist, the one for Hackett was by far the most visible, with proponents arguing that her role-like that of many women involved in labor or social activism in the early twentieth century-had been largely erased from history. Supporters launched a Facebook page and Twitter account to gather followers and organize public meetings, and an active online petition brought her previously little-known name to the foreground. ${ }^{70}$ The Hackett campaign was aided in the summer of 2013 by the centenary celebrations of the Dublin Lockout, a major industrial dispute between approximately twenty thousand Dublin workers and three hundred employers in the city between April I9I3 and January I9I4. ${ }^{71}$ Hackett received recognition as a key "forgotten" figure of the Dublin Lockout. ${ }^{72}$ The new bridge is also close to Liberty Hall, the former headquarters of the Irish Transport and General Workers' Union and the Irish Women Workers' Union, organizations to which Hackett long belonged and that played key roles in the lockout and the Irish labor movement.

The new Rosie Hackett Bridge is at the heart of Dublin City Centre. As an important new piece of public architecture to be named after a woman, it arguably has the power to "script" national memory. ${ }^{73}$ It would seem that timing was all-

Additionally, Anna Livia Bridge is named after a female personification of the River Liffey. See Dublin City Council, "Bridges of Dublin," http://www.bridgesofdublin.ie/.

69 Dublin City Council, Crossing the Liffey in Style: Rosie Hackett Bridge (Dublin City Council, 20I4), 3. http://dublincitypubliclibraries.com/sites/default/files/rosie_hackett_bridge.pdf.

70 Angela Cox, "The Rosie Hackett Bridge Campaign-The Rediscovery of a Forgotten Hero," Labour Youth (blog), September 3, 2013, http://www.labour.ie/blog/2013/o9/o3/the-rosie-hackett -bridge-campaign-the-rediscovery/.

7I Some controversy over the nominations process emerged during the campaign when Abbey Theatre, the national theater of Ireland, was not included in the eighty-five names put forward to the naming committee, chaired by Labour Party leader Dermot Lacey, after the name received 2,500 online votes. "Liffey Bridge to Be Named after Lockout Activist Rosie Hackett," Irish Times, September 3, 20I3.

72 Mary McAuliffe, ed., Rosie: Essays in Honour of Roseanna 'Rosie' Hackett (1893-1976), Revolutionary and Trade Unionist (Dublin: Arlen Press, 2015); Maeve Casserly and Laurence William White, "Rosanna 'Rosie' Hackett," Dictionary of Irish Biography, http://dib.cambridge.org/ viewReadPage.do?articleId=a9585\&searchClicked=clicked\&quickadvsearch=yes.

73 Whelan, Reinventing Modern Dublin, 157. This can be seen in the popularity of Rosie Hackett on the women's history tour of Glasnevin Cemetery, discussed in further detail in the next section of the article. Before the campaign to name the bridge after Hackett, she was almost completely unknown outside trade union circles. 
important in the city's choice. Rosie Hackett was a relatively unknown figure outside the trade union movement, and the coincidence of the bridge building and the 2013 commemoration of the lockout, as well as the hard work and organization of Labour Youth, would appear to have been pivotal her selection. ${ }^{74}$ Statues, monuments, streets, and bridges are visible reminders of a nation's history; they are trophies of a nation's "triumphs or tragedies" and tangible signs of a past that a country wants to remember openly in a public space. ${ }^{75}$ The inclusion of Hackett, alongside other popular figures remembered by bridges and monuments in the republic's capital city, is an important demonstration of the acceptance of women into the mainstream narrative of Irish history. Hackett arguably now constitutes the most visible female presence in the symbolic landscape of the capital city.

The recognition of Hackett as a nationalist and labor hero is part of a very new movement to highlight the role of diverse female figures in modern Irish history. The vast majority of the ordinary members of organizations such as the Irish Women Workers' Union, Cumann na mBan, and Inghinidhe na hÉireann have been absent from the revolutionary story until relatively recently, with the traditional narrative focused much more on those women involved in high political circles or on members of the cultural elite. This emphasis mirrors an overall concentration on political themes within Irish historiography more generally. Nonetheless, a renewed interest in the most prominent women of the period has seen their stock rise and fall in interesting and revealing ways.

\section{Women's History Beyond the "Extraordinary": Walking Tour of Glasnevin Cemetery}

On March 8, 2015, to mark International Women's Day, Glasnevin Trust offered its visitors a specially curated tour to "celebrate the famous women of Glasnevin cemetery... including revolutionaries, romantics and heroines." ${ }^{\text {"76 }}$ Walking tours are an alternative means of public engagement beyond the traditional lecture or conference and open up the cultural landscape of Irish history, particularly in important locations such as Glasnevin cemetery. ${ }^{77}$ In the promotion for the tour, the names emphasized were Anne Devlin, Countess Markievicz, and Hannah Sheehy-Skeffington, each of whom were key in the struggle for Irish political and cultural independence at the turn of the twentieth century. Sold-out groups of over

74 McAuliffe, Rosie.

75 Paula Murphy, Nineteenth-Century Irish Sculpture: Native Genius Affirmed (New Haven, CT: Yale University Press, 2010), 225. For further discussion on monumental iconography, particularly regarding the changing dynamic of postcolonial Dublin architecture, see Andrew Kincaid, Postcolonial Dublin: Imperial Legacies and the Built Environment (Minneapolis: University of Minnesota Press, 2006), iv-xiii.

76 Glasnevin Trust, “International Women’s Day Tour 20I6," http://www.glasnevintrust.ie/visit -glasnevin/events/international-womens-day/.

77 Glasnevin Cemetery is closely associated with Irish Republicanism and was described as Ireland's "Republican Valhalla" in a speech by historian Edward Madigan at the opening ceremony of the Cross of Sacrifice, Glasnevin Cemetery, July 3I, 2014. 
one hundred people attended one of two tours given that day by Bridget Sheerin, a tour guide at the cemetery who researched and curated this special women's history tour. Sheerin discussed a cross-section of women, including Irish cultural and literary figures, nationalists, unionists, suffragists, and prominent businesswomen. Among some of the lesser known featured were Mrs. Annie Mack, a wealthy madame of a series of brothels in the Monto area; Delia Larkin, a founding member of the Irish Women Workers' Union; and Sinéad DeValera, an Irish language activist and wife of former taoiseach (prime minister) and president Eamonn DeValera. Sheerin reported that the figures that provoked the greatest reaction from the crowd were, as expected, Countess Markievicz, Hannah Sheehy-Skeffington, and Maud Gonne, but other figures had gained popularity such as Rosie Hackett, Anne Devlin, and sisters Grace and Muriel Gifford. ${ }^{78}$ The popularity of the International Women's Day Tour, a paid event, demonstrated the interest from the public in engaging directly with the history of Irish women that extends beyond the iconic women who have traditionally dominated women's history in the republic.

\section{Conclusion}

There is plenty of reason to suspect that the ambivalent reception of the femalecentric RTÉ drama Rebellion was related more to its weak scripting than to its foregrounding of female protagonists. As our survey of current initiatives in public and women's history has shown, the public has evinced an appetite for challenging and variegated history with women at center stage. The centenary of the r9r6 Easter Rising has encouraged a reflection on gender equality and women's rights one hundred years on from this decisive point in Irish history. The "radical" Proclamation drawn up in I9r6 by the rebel provisional government Poblacht na hÉireann promised equality for all Irish citizens, both men and women, something now being used to interrogate an ideal that has still not been achieved in Irish society. ${ }^{79}$ On October 28, 2015, the Abbey Theatre, or the National Theatre of Ireland, announced its I9r6 centenary program, "Waking the Nation." Of the ten plays scheduled, only one was written by a woman and only three had female directors. ${ }^{80}$ In the subsequent days, a discussion erupted on Twitter and Facebook that not only lampooned the programming decision of Abbey director Fiach Mac Conghail but also highlighted the lack of female representation in Irish theatre, arts, and academia. The \#WakingTheFeminists movement evolved out of this discussion and three large public meetings have already taken place, on November I2, 2015, January 6, 2016 (Oíche Nollaig na mBan or Little Women’s Christmas), and March 8, 2016

78 Bridget Sheerin, interviewed by Maeve Casserly, July 6, 2015, Dublin, transcript in the possession of the author.

79 Olivia O'Leary, "Why, roo Years after the Easter Rising Are Irish Women Still Fighting?," Guardian, March 25, 2016; Senia Pašeta, "The Proclamation, a Feminist Doctrine," YouTube video, https://www.youtube.com/watch?v=htCsZYm9QAo.

80 Abbey Theatre, "Waking the Nation at the Abbey Theatre," press release, October 28, 2015, http://www.abbeytheatre.ie/waking-the-nation-2or6-at-the-abbey-theatre/. 
(International Women's Day). Although the group was initially founded solely to deal with gender imbalance in the theatre, it has since branched out to other disciplines of the arts and is supported by historical groups such as the All Island Commemoration Network, founded by Oona Frawley, a lecturer in Maynooth University, to tackle the gender inequality of the Decade of Centenaries (DOC) commemoration program. ${ }^{81}$ Similarly, the hashtag campaign \#NoMoreManels ("manels" being all male panels) began in early 2016 and used social media to highlight the lack of gender equality in academia. Initially it focused on the lack of female academics invited to speak at public talks and lectures during the DOC, but has become a forum of discussion on all aspects of the position of women within Irish academia. The Twitter account "Academic Manel Watch" was created in September 2016 and is run by a "collective of Irish academics against the constant \#manels \& lack of \#genderparity in Irish academia, history, arts/culture, politics, radio/TV." 82 Both the \#WakingTheFeminists and \#NoMoreManels campaigns have maintained momentum since their creation, driving a critical debate in Irish society about the "invisibility" and "exclusion" of women in the public sphere. ${ }^{83}$

The year 2016 saw a number of direct initiatives aiming at a more inclusive women's history. One example of this is a women's history project in a former British army barracks, Richmond Barracks in Inchicore, Dublin, centered on the detainment of seventy-seven female rebels following the rgr6 Easter Rising. ${ }^{84}$ The "Women and 1916" project is chaired by a committee of historians and has three features, one of which is an exhibition and biographical publication, Richmond Barrack 1916: We Were There: 77 Women of the Easter Rising by Mary McAuliffe, lecturer in University College Dublin, and independent historian Liz Gillis. The book and exhibition focus on the lives of these women and contextualize them within the social history of the period. As all seventy-seven women were detained in Richmond Barracks either en route to or from other prisons, the authors felt it was appropriate to use this story as a lens through which to commemorate the wider involvement and experience of women in the Easter Rising. ${ }^{85}$ The book was launched at the Royal Hospital Kilmainham on March 8, 2016, to mark International Women's Day. The project also involved an artistic element through the making of a quilt. Using the biographies researched by McAuliffe and Gillis, women from the communities where the detainees had lived helped make the quilt, unveiled at the book launch, that contained panels with a picture of each imprisoned woman. ${ }^{86}$ The third and ongoing component of the project explores the legacy of

8I All Island Commemoration Network Ireland website, https://allislandcommemoration networkireland.wordpress.com/.

82 Academic Manel Watch, Twitter post, December 9, 20I6, https://twitter.com/ManelWatchIre.

83 Senator Ivana Bacik, Introduction to \#WakingTheFeminists public meeting, November I2, 2015, http://www.wakingthefeminists.org/video-public-meeting-I2-november-2or5-abbey-theatre/.

84 Richmond Barracks website, http://www.richmondbarracks.ie/.

85 McAuliffe and Gillis, Richmond Barracks 1916, 4.

86 A similar project for the one hundredth anniversary of the I9I3 Dublin Lockout was run by Irish trade union SIPTU (Services Industrial Professional and Technical Union), during which 
these women through a community outreach program headed by Melanie Hoewer, lecturer in the School of Politics and International Relations in UCD. Young women from the St. Michael's and Goldenbridge communities of Inchicore will participate in group discussions on the legacies of working-class female activism, starting from the history of these seventy-seven women up to the present day. McAuliffe described the initiative as an "empowerment project," and it will incorporate members who are already involved in an outreach program run by the Women's Studies Centre within the School of Social Policy, Social Work and Social Justice at UCD, which she coordinates. ${ }^{87}$ The majority of the seventy-seven women are unknown outside specialist circles; they were young women, mostly aged between fifteen and twenty-five, working-class, inner-city, tenement dwellers, members of the ICA, Cumann na mBan, the Irish Women Workers' Union, and usually unmarried. ${ }^{88} \mathrm{Com}$ munity outreach and collaboration is the main goal of each element of the "Women and I9I6" project, showing that historical engagement with the public can go beyond traditional state-led commemoration days.

McAuliffe and Gillis recognized that the focus on these particular women examined a "minority within a minority" and that the experience of many other women, including unionists, looters, separation wives, and pacifists, would not be reflected in the study. ${ }^{89}$ However, the "Women and I9I6" project represents an important addition to scholarly research into this period. In the context of malecentric commemorations this study complicates that narrative and demonstrates, in particular, the links between the campaigns for national freedom, women's suffrage, and a socialist republic, making it a significant addition to the study of modern Irish history as a whole. The project hopes to show that the contribution of these women to the Easter Rising was equal to that of their male counterparts, and that these women viewed it as such.

The future of women's history and public history in Ireland looks no less intertwined than twenty years ago, and positive and progressive developments in both fields are traceable across the republic. Public history aims for shared authority and allows historians and practitioners to engage with a broad public and to do history with them. If the public response to women's history initiatives in Ireland can tell us anything it is that there is a large public appetite for Irish women's history, and that the extent of that is still undetermined. We have on hand, for the first time, a source base of primary material from memoirs, diaries, and

members of SIPTU and inner-city Dublin communities wove a tapestry depicting key scenes from the lockout. The tapestry, commissioned by SIPTU and the National College of Art and Design, was unveiled by President Michael D. Higgins in September 2013 in the SIPTU headquarters in Liberty Hall, Dublin I; See "I9I3 Lockout Tapestry on Display in Pearse Street Library," SIPTU website, February 13, 2015, http://www.siptu.ie/media/newsarchive2015/fullstory_18848_en.html.

87 "Engagement," School of Social Policy, Social Work and Social Justice, University College Dublin, http://www.ucd.ie/socialpolicyworkjustice/research/socialimpact/engagement/.

88 "Women and I9ı6," Richmond Barracks website, http://www.richmondbarracks.ie/women -I9r6/women-detainees-list/.

89 McAuliffe and Gillis, Richmond Barracks 1916, 6. 
correspondence. Recent work by R. F. Foster and Lucy MacDiarmid is suggestive of what talented historians can do with such material, but crowdsourcing projects such as the "Letters of 1916" and "Inspiring Ireland" projects suggest what might also be possible with an engaged public. ${ }^{90}$ Resources such as the Bureau of Military History Archives and the Military Service Pension Collection, which have been prioritized in digitization and conservation initiatives during the Decade of Centenaries, contain much material that the public can mine. An increased presence of women in Irish history departments is of paramount importance to a greater equality in public history and women's history, but it is far from the only factor. The invisibility of women across historical platforms is endemic. No major documentary series on history in Ireland has ever been fronted by a woman. Almost all history programming across televisual and radio broadcasting is presented and produced by men. Rebellion was notable for its female protagonists, but the series was written and directed by men. These are significant systemic issues. Change will come at the macro level, and in the meantime there is much to learn from the micro.

Touring exhibitions such as Modern Wife, Modern Life help to broaden the discussion beyond the revolutionary period. Engaging with public space and cultural landscape represents one way in which the "script" of women's history can be rewritten in Ireland. Walking tours of women's history such as that staged in Glasnevin Cemetery on International Women's Day 2015 can disrupt the normative narrative, but would stand a better chance if not restricted to one day a year. This space will need to be claimed in the same way as the \#WakingTheFeminists campaign has claimed a place for woman in the arts. What is there to be said for WakingTheHistorians?

Ciaran O'Neill is co-director of the M.Phil. in the Public History and Cultural History program at Trinity College Dublin, Ireland. He has published widely on Irish and British history and literature, as well as public history. Recent publications include Catholics of Consequence: Transnational Education, Social Mobility, and the Irish Catholic Elite 1850-190o (Oxford University Press, 2014), and in 2016 he guest edited a special issue of Eire-Ireland with Enda Delaney for the Transnational Ireland Network.

Maeve Casserly is a $\mathrm{PhD}$ candidate in the School of History, University College Dublin. Her research focuses on the centenary commemorations of the Easter Rising and the Battle of the Somme in the republic and Northern Ireland. She is an education assistant in the National Library of Ireland Outreach Department. She has written and presented widely on her $\mathrm{PhD}$ research as well as on her work as a public history practitioner in the National Library of Ireland's contribution to the Irish Decade of Centenaries.

90 Roy Foster, Vivid Faces: The Revolutionary Generation of Ireland, 1890-1923 (London: Penguin, 2015); Lucy McDiarmid, At Home in the Revolution: What Women Said and Did in 1916 (Dublin: Royal Irish Academy, 2015). 